\title{
Timing of the deglaciation and the late-glacial vegetation development on the Pandivere Upland, North Estonia
}

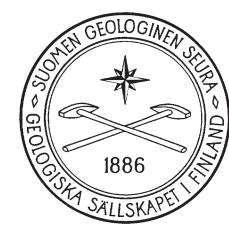

VERTAISARVIOITU KOLLEGIALT GRANSKAD PEER-REVIEWED
www.tsv.fi/tunnus

\author{
Leeli Amon, Leili SaArse, Jüri Vassiljev, Atko Heinsalu \\ AND SIIM VESKI
}

Institute of Geology at Tallinn University of Technology, Ehitajate tee 5, 19086 Tallinn, Estonia.

\section{Abstract}

In this study, the deglaciation chronology of the Pandivere Upland is defined, and the late-glacial vegetation trends of north-eastern Estonia are summarised. The multi-proxy study includes accelerated mass spectrometry ${ }^{14} \mathrm{C}$ dating, plant macrofossil, magnetic susceptibility, loss-on-ignition and grain-size distribution data of the lacustrine sediment record from one previously unpublished study site (Kursi), and the study discusses the results in combination with five previously published study locations from the area.

The results indicate that the deglaciation of the Pandivere Upland started at approximately 14200 cal. yr BP and was completed by 13800 cal. yr BP. The ice recession rate was approximately $180 \mathrm{~m} \mathrm{yr}^{1}$. Based on these new radiocarbon dates, the Baltic Ice Lake stage $A_{1}$ submerged the northern and western ice-free areas of Estonia by ca. 13800 cal. yr BP. The prevalent vegetation type in north-eastern Estonia during the late-glacial period was tundra with local variations in the dominant shrub species. The region remained treeless until the Holocene.

Keywords: deglaciation, lithology, chronology, plant macrofossils, North Estonia

*Corresponding author (e-mail: leeli.amon-veskimeister@ttu.ee)

Editorial handling: Juha Pekka Lunkka (juha.pekka.lunkka@oulu.fi) 


\section{Introduction}

Investigation of the spatial pattern and timing of the ice-sheet retreat of the last Scandinavian glaciation, as well as of the postglacial vegetation dynamics in Estonia, has a long history (e.g. Hausen, 1913; Thomson, 1929; Ramsay, 1929; Tammekann, 1938). Hausen (1913) showed that several marginal moraine chains were formed in front of the retreating ice margin, and Tammekann (1938) distinguished five ice-marginal belts (the Haanja, Otepää, Sakala, Pandivere and Palivere). This fivefold structure of ice retreat still holds true today. Ice-marginal belts mark standstills of the ice termini or small-scale readvances (Zelčs \& Nartišs, 2014). To date these belts, different methods have been applied, such as optically stimulated luminescence (OSL), cosmogenic ${ }^{10} \mathrm{Be}$ exposure dating, varve chronology, conventional and Accelerator Mass Spectrometry (AMS) radiocarbon dating and pollen analyses (Pirrus, 1965; Pirrus \& Raukas, 1996; Sandgren et al., 1997; Raukas, 2004; Raukas \& Stankowski, 2005; Kalm, 2006, 2012; Kalm et al., 2011; Rosentau, 2006; Saarse et al., 2012; Lasberg \& Kalm, 2013). However, the estimations of the time of the deglaciation vary notably by approach.

Studying varved clays in north-eastern Estonia, Rähni (1963) identified a spatially distributed marker horizon (a so-called drainage varve), and correlated it to an age of 12080-12050 years (Raukas et al., 1971). This assessment was considered for several years to be the calendar age of the Pandivere marginal formations (Raukas, 1986; Raukas \& Karukäpp, 1993). In later publications Raukas (2009) suggested that ice retreated from Pandivere ca. $12300{ }^{14} \mathrm{C}$ yr BP (calendar age -14 100-14300 cal. yr BP). This estimation is older than recently suggested (Kalm, 2012; Saarse et al., 2012; Lasberg \& Kalm, 2013; Vassiljev \& Saarse, 2013) and does not fit with ${ }^{10}$ Be-based dates, which indicate that the Pandivere belt formed $13100 \pm 1100{ }^{10} \mathrm{Be}$ years BP (Rinterknecht et al., 2006). The varved clay results and their correlation with the Neva ice marginal belt (Saarnisto \& Saarinen, 2001) provide grounds for estimating the age of the Pandivere stadial at 12700 varve years
(Hang, 1997), redefined to 13300 varve years by Hang (2003) and later to more than $13300 \mathrm{cal}$. yr BP (Hang \& Kohv, 2013). Saarse et al. (2007) proposed that the proglacial lake $A_{1}$, a bay of the Baltic Ice Lake (BIL) formed between the retreating ice margin and the slope of the Pandivere Upland, is approximately $13300 \mathrm{cal}$. yr BP old. However, recent AMS radiocarbon dates from the Haljala and Udriku sites (Fig. 1A) indicate ages over 500 years older than 13300 cal. yr BP (Amon \& Saarse, 2010; Saarse et al., 2012).

Despite the long history of palaeobotanical research in Estonia, it has been possible to build a realistic temporal framework to the late-glacial vegetation dynamics only during recent decades through the advances in radiocarbon dating technique. The local late-glacial minerogenic sediments contain very little, but sufficient, organic (terrestrial) material for AMS ${ }^{14} \mathrm{C}$ dating and palaeobotanical studies (e.g. Amon \& Saarse, 2010; Amon et al., 2014). So far, the plant macrofossil data indicates that the late-glacial treeline was located in southern Estonia (Amon et al., 2014), but new sites in northern Estonia help to define the detailed dynamics of the treeless tundra.

In this paper, new lithological, palaeobotanical and AMS ${ }^{14} \mathrm{C}$ data from an overgrown Lake Kursi in Savalduma Bog are reported to determine the deglaciation of the Pandivere Upland with particular emphasis on the formation of the ice marginal belt and to describe the late-glacial local vegetation dynamics. For this purpose, the earlier studied and dated sites (Prossa, Räätsma, Äntu, Udriku, Haljala; Fig. 1A; Table 1) are also discussed.

\section{Regional Setting and Study Sites}

Pandivere is a plinth-type bedrock upland located between the Peipsi-Pihkva and West Estonian ice lobes (Karukäpp, 1997), also known as the PeipsiPskov and Vórtsjärv ice streams, respectively (Kalm, 2012). The upland has a carbonaceous bedrock core and thin Quaternary cover. The Pandivere belt was 
formed during the ice margin termination at the upland slope and is marked in the east by kames, esker and moraine ridges, in the north mostly by glaciofluvial deltas and kames, and in the west by long chains of esker and moraine ridges. Lakes on the Pandivere Upland occupy basins in the bedrock depressions and hollows of the limestone outcrop, which in some cases were deepened by karst processes and fed by precipitation, inflow streams and bottom springs. Many of the lakes have alkaline water and calcareous sediments (Saarse, 1994).

The Pandivere Upland is an important landform associated with the BIL stages (Rosentau et al., 2009; Vassiljev \& Saarse, 2013). The highest shoreline of the BIL (stage $A_{1}$ ) formed at the same time as the Pandivere ice marginal zone and the following stage $A_{2}$ formed in the front of the next ice marginal zone, Palivere (Vassiljev \& Saarse, 2013).
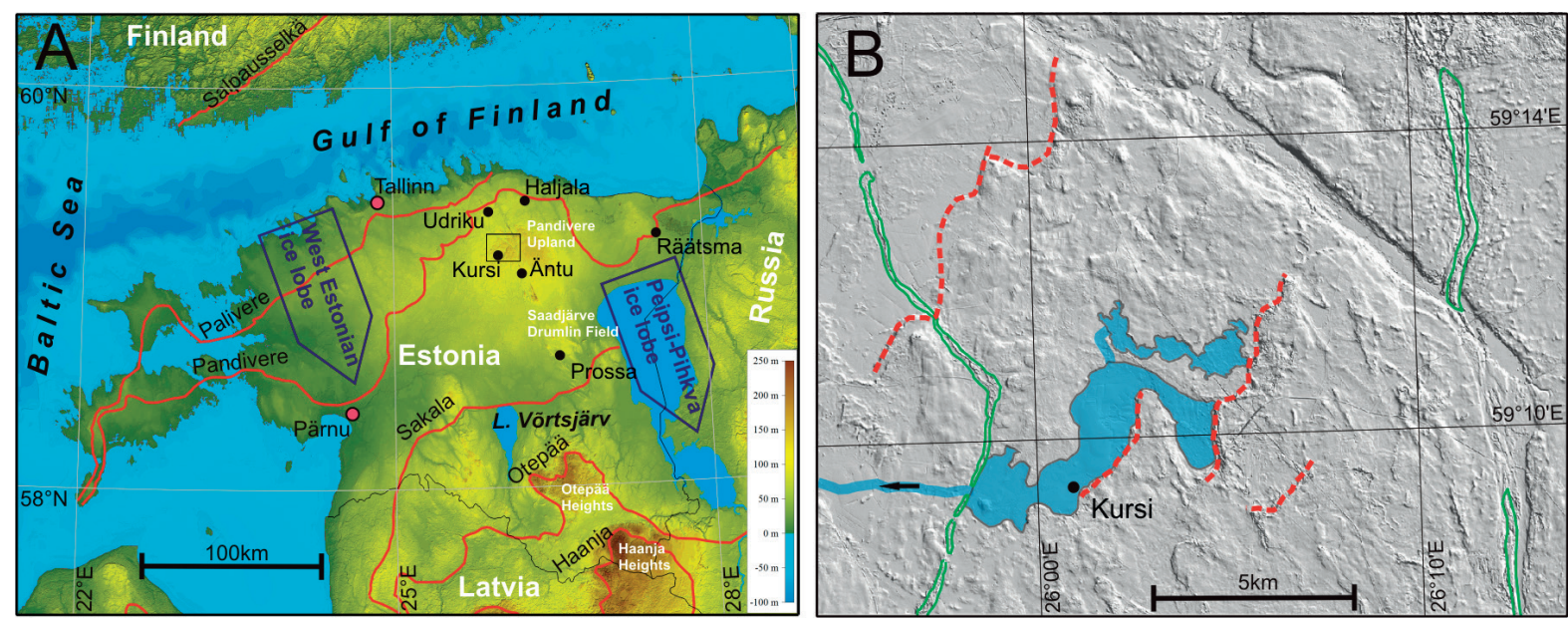

Fig. 1. Overview map of the study area (A) with ice-marginal belts (red lines) and ice lobes (blue arrows). The black rectangle marks the area shown on Fig. 1B. Shaded relief map shows the location of the coring site (black circle) at Lake Kursi (B). The red lines mark the ice contact slopes and the green lines eskers. The blue area indicates the approximate location of the local ice-dammed lake and the black arrow a possible outflow channel.

Table 1. The characteristics of the study sites.

\begin{tabular}{|c|c|c|c|c|c|}
\hline \multicolumn{6}{|c|}{ Lakes beyond the Pandivere Upland } \\
\hline & Coordinates & Size, ha & Depth, $m$ & Height, ma.s.I. & References \\
\hline Prossa & $\begin{array}{l}58^{\circ} 38^{\prime} 57^{\prime \prime} \mathrm{N}, \\
26^{\circ} 34^{\prime} 40^{\prime \prime} \mathrm{E}\end{array}$ & 24.2 & 5 & 61 & $\begin{array}{l}\text { Saarse \& Kärson, 1982; Rõuk, 1987; } \\
\text { Saarse, 1994; Rosentau et al., 2007; } \\
\text { Kihno et al., } 2011\end{array}$ \\
\hline Räätsma & $\begin{array}{l}59^{\circ} 14^{\prime} 16^{\prime} \mathrm{N}, \\
27^{\circ} 33^{\prime} 21^{\prime} \mathrm{E}\end{array}$ & 16.4 & 10.8 & 45 & Saarse et al., 1985; Saarse, 1994 \\
\hline \multicolumn{6}{|c|}{ Lakes on Pandivere Upland } \\
\hline & Coordinates & Size, ha & Depth, $m$ & Height, ma.s.I. & References \\
\hline Kursi & $\begin{array}{l}59^{\circ} 09^{\prime} 21^{\prime \prime N} \\
26^{\circ} 00^{\prime} 56^{\prime \prime} \mathrm{E}\end{array}$ & - & - & 112 & Veber, 1961, 1965; present study \\
\hline Äntu (Sinijärv) & $\begin{array}{l}59^{\circ} 03^{\prime} 45.8^{\prime \prime} \mathrm{N} \\
26^{\circ} 14^{\prime} 24.8^{\prime \prime} \mathrm{E}\end{array}$ & 2.4 & 7.3 & 94.6 & $\begin{array}{l}\text { Saarse \& Liiva, 1995; Sohar \& Kalm, } \\
\text { 2008, Laumets et al., } 2014\end{array}$ \\
\hline Udriku (Suurjärv) & $\begin{array}{l}59^{\circ} 22^{\prime} 17^{\prime \prime} \mathrm{N} \\
25^{\circ} 55^{\prime} 50^{\prime \prime} \mathrm{E}\end{array}$ & 23.7 & 6.8 & 95 & Saarse, 1994; Amon \& Saarse, 2010 \\
\hline Haljala paleolake & $\begin{array}{l}59^{\circ} 25^{\prime} 27^{\prime} \mathrm{N}, \\
26^{\circ} 17^{\prime} 42^{\prime}-\mathrm{E}\end{array}$ & - & - & 67.4 & Saarse etal., 2007,2009 \\
\hline
\end{tabular}


The present paper combines the chronologies of lakes beyond (Prossa and Räätsma) and on the Pandivere Upland (Kursi, Äntu, Udriku and Haljala) (Table 1). The previously unpublished study site, Kursi $\left(59^{\circ} 09^{\prime} 21^{\prime \prime} \mathrm{N}, 26^{\circ} 00^{\prime} 56^{\prime \prime} \mathrm{E}\right)$, is located in the central part of the Pandivere Upland at the edge of the Savalduma Bog (Fig. 1), where karst is widespread. Limestone of the Tamsalu regional stage outcrops east of the lake, and along the outcrop is a steep cleavage filled with water (Fig. 1B). Lake Kursi is located at the edge of the ancient Porkuni ice-dammed lake whose water level reached $128 \mathrm{~m}$ a.s.l. (Rähni, 1961), with a threshold at $112 \mathrm{~m}$ a.s.l. (Öpik, 1937) (Fig. 1). The ice margin position during the existence of this glacial lake was reconstructed by Ramsay (1929) and Öpik (1937), but the timing was not determined. In this short-lived ice-dammed lake, up to 1-m-thick glaciolacustrine sediments were deposited. The pollen composition of the sediments was studied by Veber (1961, 1965), and an age was determined in this study based on four AMS ${ }^{14} \mathrm{C}$ dates (Table 2).

\section{Materials and Methods}

\subsection{Coring and lithostratigraphy}

Macrofossils, grain-size composition, loss-onignition (LOI), magnetic susceptibility (MS) and AMS radiocarbon dates were determined from the overlapping cores, which were extracted from Lake Kursi with a 1-m-long Russian peat sampler. The cores were described and photographed in the field, packed into plastic tubes, wrapped in polyethylene film, transported to the laboratory and stored in a cool room. One-centimetre-thick subsamples were taken continuously for LOI analyses, and 1-cmthick samples were taken to measure the grain size distribution at $2-\mathrm{cm}$ intervals. Bulk samples for LOI were weighted, dried at $105{ }^{\circ} \mathrm{C}$ overnight, and combusted at 525 and $900{ }^{\circ} \mathrm{C}$ to calculate the water, organic matter (OM), carbonate and minerogenic (MM) content (Fig. 2). The grain size was analysed using a Horiba Instruments LA950 V2 laser scattering particle size distribution analyser (Figs 3A, B). To avoid the effect of OM and carbonates, samples were pre-treated with 30\% hydrogen peroxide $\left(\mathrm{H}_{2} \mathrm{O}_{2}\right)$ and $10 \% \mathrm{HCl}$. Grain size classification follows the Udden-Wentworth scale (Last, 2001). MS was measured with a Bartington Instruments MS2E high-resolution surface scanning sensor at a resolution of $1 \mathrm{~cm}$ along carefully cleaned flat surfaces of fresh sediments covered by a thin plastic film.

\subsection{Palaeoecological methods}

Sediment samples for plant macrofossil analysis $\left(80-200 \mathrm{~cm}^{3}\right)$ and AMS ${ }^{14} \mathrm{C}$ dating were soaked in water and sieved through a $0.2-\mathrm{mm}$ mesh. The plant remains were identified under a binocular microscope. Pollen from the Lake Kursi core was analysed by Veber (1965), and the results are presented in Figure 4B. The LOI, plant macrofossil and pollen diagrams were plotted with the TILIA and TGView programmes (Grimm, 2011).

\subsection{Chronology}

The AMS radiocarbon ages were determined in the Poznan radiocarbon laboratory from the terrestrial macrofossils Salix polaris, Dryas octopetala leaves, and bulk gyttja (Table 2). The late-glacial chronostratigraphy is presented in calendar and ice-core years (Lowe et al., 2008) and all ${ }^{14} \mathrm{C}$ dates, including those previously published, were calibrated using IntCal13 calibration data set and Oxcal 4.2 software (Bronk-Ramsey, 2009). In the present study, calibrated ages (cal. yr BP relative to AD 1950) are used (Table 2). Radiocarbon dating from Lake Räätsma and one basal dating from Lake Äntu were performed in the Tartu Radiocarbon Laboratory (index TA). 
Table 2. Radiocarbon dates of sites used in setting up deglaciation chronology.

\begin{tabular}{|c|c|c|c|c|c|}
\hline $\begin{array}{l}\text { Site name } \\
\text { Depth, cm }\end{array}$ & ${ }^{14} \mathrm{C}$ date & $\begin{array}{l}\text { Radiocarbon } \\
\text { lab. no. }\end{array}$ & $\begin{array}{l}\text { Calibrated age } \\
\text { (weighted average } \\
\text { cal.yr BP) }\end{array}$ & Material dated & Reference \\
\hline \multicolumn{6}{|l|}{ Lake Udriku } \\
\hline $745-750$ & $10590 \pm 60$ & Poz-30429 & $12420-12690$ & Dryas leaves & Amon \& Saarse, 2010 \\
\hline $768-773$ & $11240 \pm 100$ & Poz-36168 & $13060-13130$ & Dryas leaves & Amon \& Saarse, 2010 \\
\hline $798-803$ & $11890 \pm 80$ & Poz-30430 & $13490-13970$ & Dryas leaves & Amon \& Saarse, 2010 \\
\hline 813-818 & $12090 \pm 80$ & Poz-36201 & $13760-14140$ & Dryas leaves & Amon \& Saarse, 2010 \\
\hline \multicolumn{6}{|c|}{ Palaeolake Haljala } \\
\hline 310-315 & $11780 \pm 60$ & Poz-22530 & $13470-13740$ & Plant remains & Saarse et al., 2009 \\
\hline $410-415$ & $11750 \pm 80$ & Poz-22531 & $13440-13750$ & Plant remains & Saarse et al., 2009 \\
\hline \multicolumn{6}{|l|}{ Lake Äntu } \\
\hline $740-750$ & $10930 \pm 200$ & TA-2119 & $12430-13240$ & Plant remains & Saarse \& Liiva, 1995 \\
\hline 816 & $10840 \pm 60$ & Poz-19684 & $12670-12830$ & Gyttja & Sohar \& Kalm, 2008 \\
\hline $720-723$ & $10960 \pm 70$ & Poz-25542 & $12710-13000$ & Wood & Laumets etal., 2014 \\
\hline \multicolumn{6}{|c|}{ Lake Räätsma } \\
\hline $530-540$ & $12040 \pm 100$ & TA-688 & $13620-14160$ & Bryales moss & Ilves, 1980 \\
\hline $360-370$ & $12050 \pm 120$ & TA-686 & $13580-14210$ & Plant remains & Ilves, 1980 \\
\hline \multicolumn{6}{|l|}{ Lake Kursi } \\
\hline $258-259$ & $9870 \pm 50$ & Poz-67317 & $\begin{array}{l}11200-11400 \\
(11290 \pm 60)\end{array}$ & Bulk gyttja & Currentstudy \\
\hline 299-301 & $11800 \pm 60$ & Poz-69661 & $\begin{array}{l}13480-13750 \\
(13630 \pm 70)\end{array}$ & Dryas leaves & Currentstudy \\
\hline $307-309$ & $11970 \pm 70$ & Poz-69556 & $\begin{array}{l}13600-14030 \\
(13830 \pm 110)\end{array}$ & $\begin{array}{l}\text { Salix polaris } \\
\text { leaves }\end{array}$ & Current study \\
\hline 313-315 & $12020 \pm 100$ & Poz-69557 & $\begin{array}{l}13600-14120 \\
(13880 \pm 130)\end{array}$ & $\begin{array}{l}\text { Salix polaris } \\
\text { leaves }\end{array}$ & Currentstudy \\
\hline \multicolumn{6}{|c|}{ Lake Prossa } \\
\hline $550-555$ & $10710 \pm 50$ & Poz-35466 & $12580-12730$ & Plant remains & Kihno et al., 2011 \\
\hline $595-600$ & $11650 \pm 50$ & Poz-35467 & $13380-13580$ & Plant remains & Kihno et al., 2011 \\
\hline $625-630$ & $12330 \pm 60$ & Poz-35468 & $14080-14700$ & Plant remains & Kihno et al., 2011 \\
\hline $645-650$ & $12380 \pm 70$ & Poz-36169 & $14110-14850$ & Plant remains & Kihno etal., 2011 \\
\hline
\end{tabular}




\section{Results}

\subsection{Lithology}

The litho-, bio- and chronostratigraphies of Prossa (Kihno et al., 2011), Räätsma (Saarse, 1994), Äntu (Saarse \& Liiva, 1995; Laumets et al., 2014), Udriku (Saarse, 1994; Amon \& Saarse, 2010) and Haljala (Saarse et al., 2009, 2012) have been previously published. In this study, we focus on the results of the Lake Kursi late-glacial sediments.

The basal unit in Lake Kursi is till (Table 3), which contains approximately 50\% crystalline and carbonate clasts. OM accounts for $1 \%$ of the sediment, carbonates for $16 \%$, and other mineral matter for $83 \%$ (Fig. 2). MS values reach up to $17 \times 10^{-5}$. The basal till is overlain by varved clay $(333-316 \mathrm{~cm})$ containing a total of 20 varves. The clay content is high, up to $60 \%$, whereas the OM percentage is low, accounting for only $2-3 \%$. The non-carbonate $\mathrm{MM}$ increases to $83 \%$, whereas carbonates decrease from $30 \%$ to $14 \%$, showing a reverse trend. At a core depth of $330 \mathrm{~cm}$, MS has a clear peak of $90 \times 10^{-5}$. Varved clay is overlain by 0.5 -cm-thick sand $(316-315.5 \mathrm{~cm})$ rich in plant remains and clayey silt with a rhythmic pattern $(315.5-299 \mathrm{~cm})$ rich in Drepanocladus moss fragments. In the overlying clayey silt, the OM content is low, accounting for $1-3 \%$ (Fig. 2). The sand fraction in the mineral portion of the sediment is $9-19 \%$, the clay fraction fluctuates between 3\% and $8 \%$, and the silt fraction ranges from $75 \%$ and
$87 \%$ (Fig. 3). The sandy silt at $299-283 \mathrm{~cm}$ differs from the underlying clayey silt with a massive texture, increased sand (19-33\%) and OM (3$7 \%)$ content and decreased carbonate percentages $(3-10 \%)$. In the next unit $(283-259 \mathrm{~cm})$, the sand fraction reaches $50 \%$, clay is present sporadically at low values (0-3\%), OM (mostly from water mosses) fluctuates between $4 \%$ and $13 \%$, and carbonates decrease to $1-2 \%$ (Fig. 2). In gyttja (259-240 $\mathrm{cm})$, OM rapidly reaches $60-70 \%$. Late-glacial lithostratigraphy in Kursi is rather similar to that of the Saadjärv Drumlin Field lake sediments where varved clays are also overlain by silt-clay rhytmites, grey massive silt and greenish grey silt with water mosses (Rosentau et al., 2007).

\subsection{Chronostratigraphy}

Radiocarbon dates defining the deglaciation age of the Pandivere Upland and the formation of the icemarginal belt are presented in Table 2. The basal till and varved clay of Kursi was barren of terrestrial macrofossils, containing only a few fragments of the water moss Drepanocladus. Salix polaris leaves were present in the laminated silt between 315.5 and $308 \mathrm{~cm}$ at core depths of 313-315 cm dated to $12020 \pm 100{ }^{14} \mathrm{C}$ yr BP $(13880 \pm 130$ cal. yr BP $)$ and $307-309 \mathrm{~cm}$ dated to $11970 \pm 70{ }^{14} \mathrm{C}$ yr BP $(13830 \pm 110 \mathrm{cal}$. yr BP). The silt between 307 and $299 \mathrm{~cm}$ mostly contained Dryas octopetala leaves, with the depth interval of 299-301 cm dated to $11800 \pm 60{ }^{14} \mathrm{C}$ yr BP $(13630 \pm 70 \mathrm{cal}$. yr BP $)$. One

Table 3. Sediment lithology of Lake Kursi.

\begin{tabular}{ll}
\hline Depth, cm & Sediment description \\
\hline $0-50$ & sod \\
$50-259$ & gyttja, dark brown, unconsolidated \\
$259-283$ & sandy silt, greenish grey, with dispersed OM \\
$283-299$ & sandy silt, greenish grey, with Drepanocladus fragments \\
$299-315.5$ & laminated clayey silt, greenish grey, between 308-315.5 cm \\
& rich in mosses \\
$315.5-316$ & sand, grey, with plant remains \\
$316-333$ & varved clay, brownish grey \\
$333-335+$ & till, grey, rich in clast
\end{tabular}




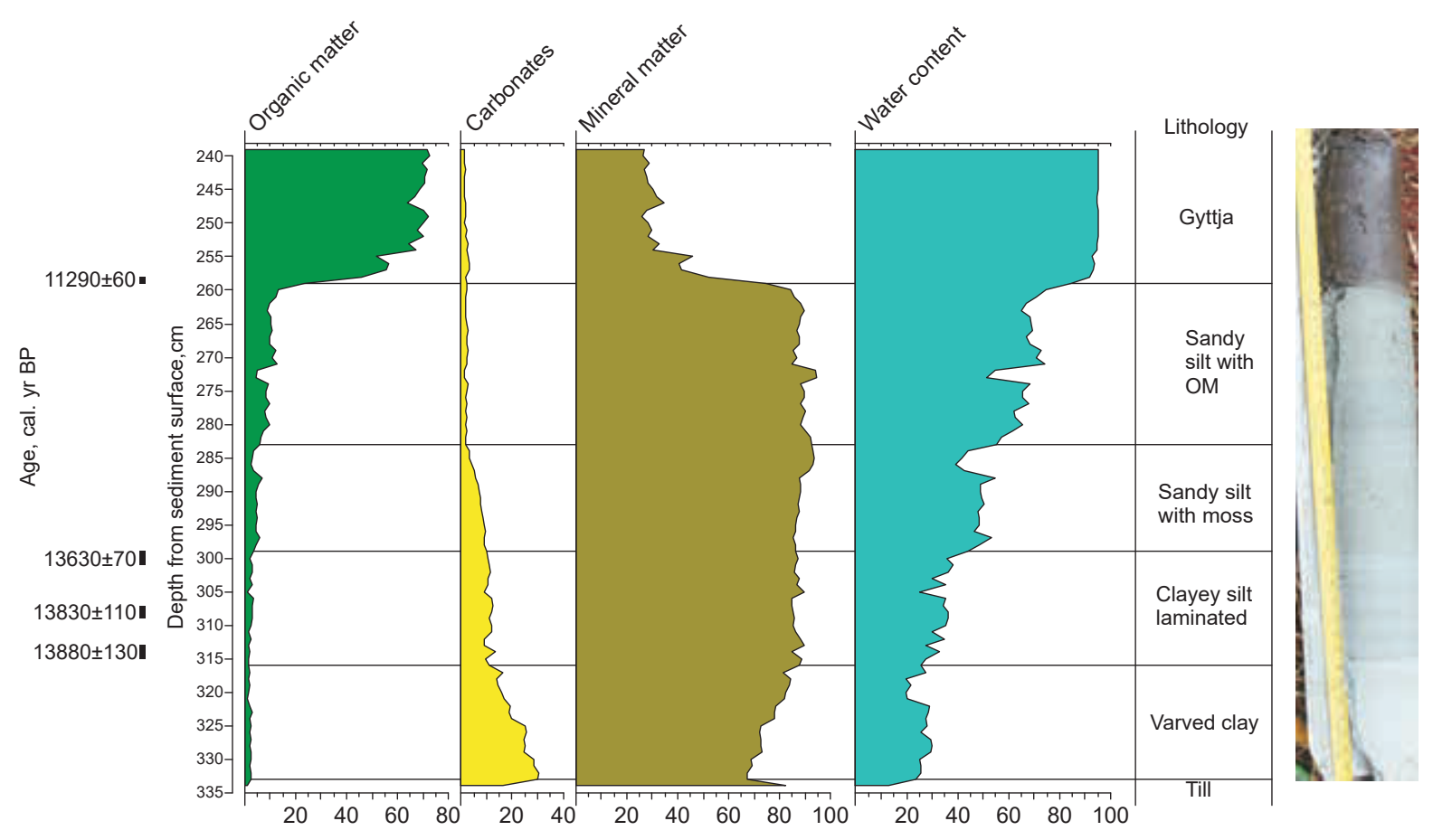

Fig. 2. Lithostratigraphy, loss-on-ignition (OM, MM and carbonates content), calibrated radiocarbon dates and a photograph of the Lake Kursi sediment core.

A

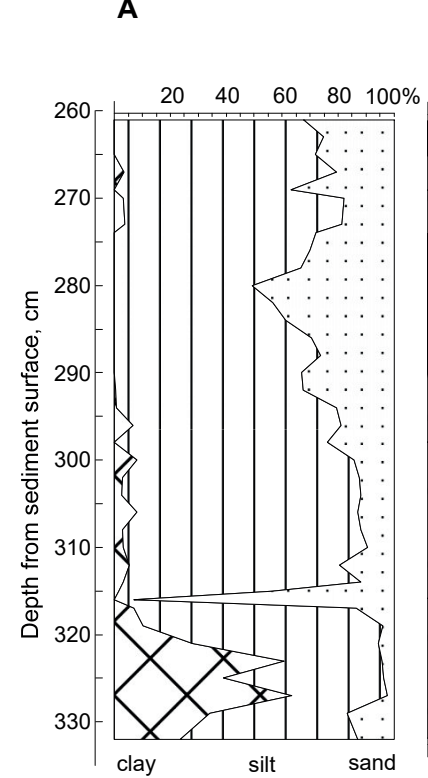

B

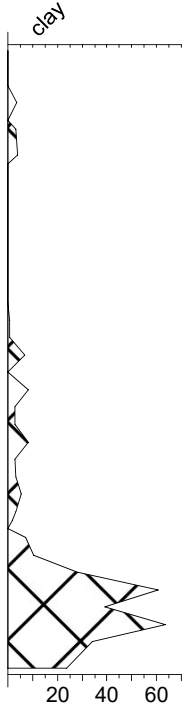

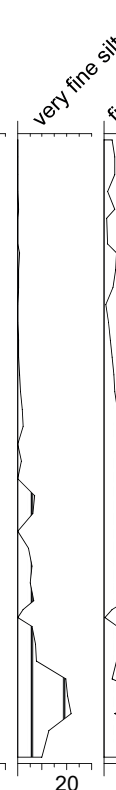
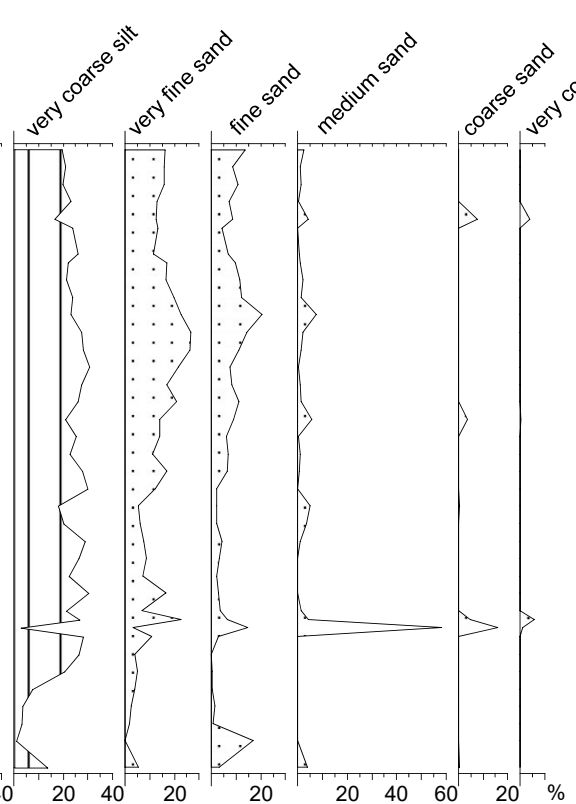

Fig. 3. Diagram showing grain size distribution characteristics of Lake Kursi late-glacial sediments (A) and the detailed grain size distribution of Lake Kursi late-glacial sediments (B). 
bulk gyttja at $258-259 \mathrm{~cm}$ in contact with clayey strata was dated at $9870 \pm 50{ }^{14} \mathrm{C}$ yr BP $(11290 \pm 60$ cal. yr BP), which is a Holocene age. Based on the radiocarbon dates and the sediment thickness, the laminated clayey-silt (rhythmites) between 315.5 and $299 \mathrm{~cm}$ were deposited over 250 years at an average sedimentation rate of $<0.7 \mathrm{~mm} \mathrm{yr}^{-1}$, and the silt between 299 and $259 \mathrm{~cm}$ was deposited over 2340 years at an average sedimentation rate of only $<0.2 \mathrm{~mm} \mathrm{yr}^{-1}$. The low sedimentation rate, the sharp limit between organic and minerogenic sediments and the changes in pollen data obviously indicate a hiatus in the core.

It is important to stress that the AMS ${ }^{14} \mathrm{C}$ date of 13880 cal. yr BP for Kursi (Table 2) reflects the age when the sedimentary basin was surrounded by vegetation that was deposited into the sediments and thus could be dated. The basal date does not include the age of the varved clays and thus reflects the onset of sedimentation with a delay. The only site where the varved clays contained Salix polaris leaves was Udriku, which was dated to $13950 \pm 110$ cal. yr BP.

\subsection{Biostratigraphy}

The basal part of the sediment of Lake Kursi, the varved clay, contained no terrestrial macrofossils. Betula and Pinus pollen are common, accounting for $26-33 \%$ and $18-33 \%$ of the total pollen, respectively (Veber, 1965, Fig. 4B) - however, the tree pollen grains are not local but were transported over long distances or partially reworked from older sediments.

Willow dwarf shrub (Salix polaris) macrofossils appear in the lower portion of the laminated silt (Fig. 4A) with occasional finds of different mosses (Scorpidium sp., Calliergon sp.). In the upper part of the same portion of sediment, the number of willow dwarf shrub macrofossils declines. Meanwhile, Dryas octopetala leaves appear from core depth $303 \mathrm{~cm}(\sim 13700 \mathrm{cal}$. yr BP) to core depth $280 \mathrm{~cm}$, where their numbers decrease. The other macrofossils found besides Dryas include water moss leaves, Sphagnum, different herbs (Poaceae,
Juncus spp., Ranunculus section Batrachium) and Nitella oospores. At core depth $280 \mathrm{~cm}$, numerous dwarf birch remains are observed in one sample. The samples between depths of 280-260 cm are practically void of terrestrial plant macrofossils except for a fragment of Dryas leaf. The Younger Dryas silt in Kursi was characterized by only one pollen sample, in which Betula accounted for $1 \%$, Pinus for 23\%, Picea for 3\%, and Alnus for $2 \%$ (Veber, 1965). Among NAP, the same taxa dominated as in the Allerød portion of the sediment, but the ratio of AP to NAP was slightly inclined (51\%) towards NAP. Again, the tree pollen is a result of long distance transportation since plant macrofossil results clearly indicate that the local vegetation was typical of treeless tundra. At core depth $260 \mathrm{~cm}$, the sediment type changes distinctively from silt to gyttja. The macrofossils found in gyttja belong to tree-birch and Menyanthes trifoliata.

\section{Discussion}

\subsection{Timing of the deglaciation of the Pandivere Upland}

The chronologies from the present study sites help to clarify the timing of the deglaciation of the Pandivere Upland. The southernmost study site, Lake Prossa, is located between the Otepää and Pandivere marginal belts. Based on previous studies, the surroundings of Lake Prossa became ice-free approximately $14400 \mathrm{cal}$. yr BP (Kihno et al., 2011, Table 2), which is consistent with the proposed age of the Otepää zone (14700-14500 cal. yr BP; Lasberg \& Kalm, 2013). Over the next 150 years, the area around Prossa was submerged by waters of a proglacial lake deduced from ca. 5-m-thick varved clay and clayey rhythmites occurring in lakes of the Saadjärv Drumlin Field (Rosentau et al., 2007).

The distance between the Otepää marginal belt and Prossa is ca. $45 \mathrm{~km}$ and the deglaciation age differs by 300 years. From this, we estimate the calculated annual ice recession rate was $\sim 150 \mathrm{~m} \mathrm{yr}^{-1}$, 
Fig. 4. The scheme of the dynamics of the late-glacial local vegetation types around Lake Kursi (A) and the modified tree pollen diagram from Lake Kursi (after Veber 1965) (B).
A

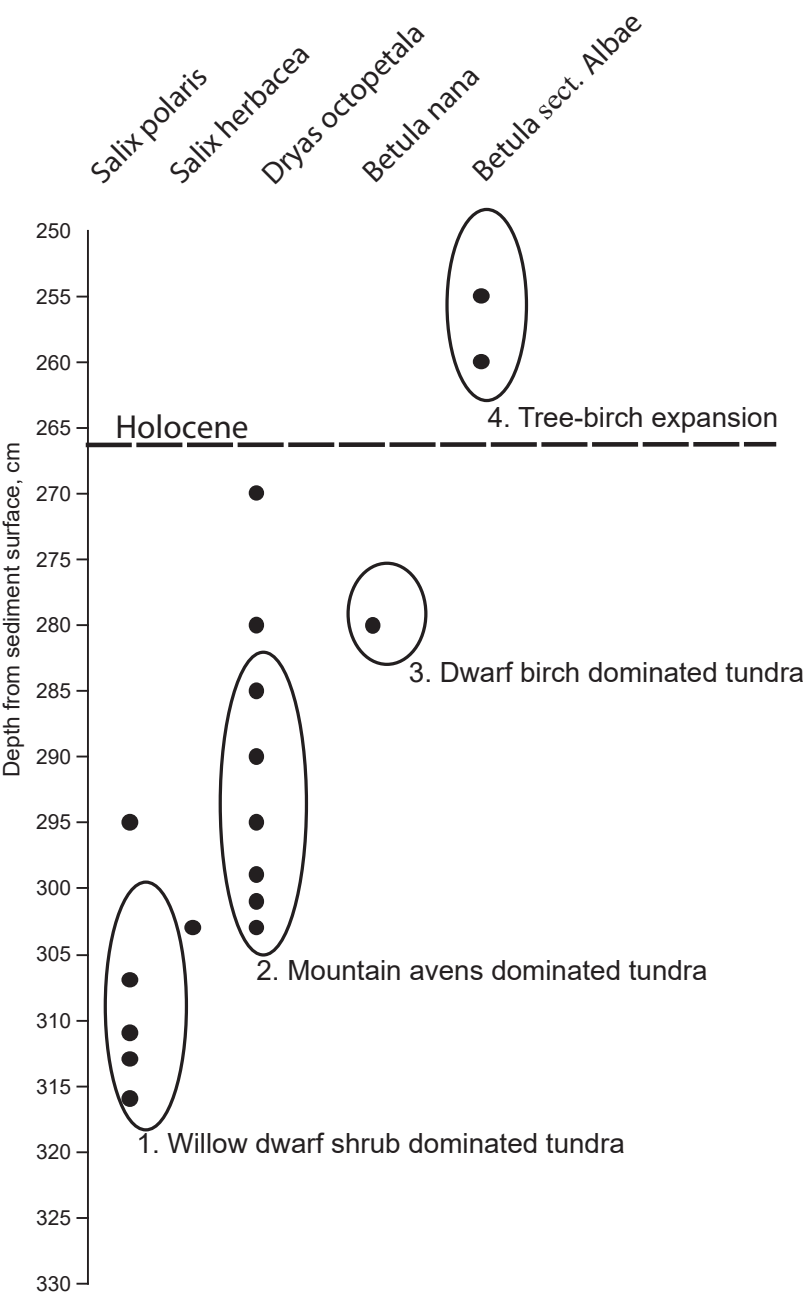

B

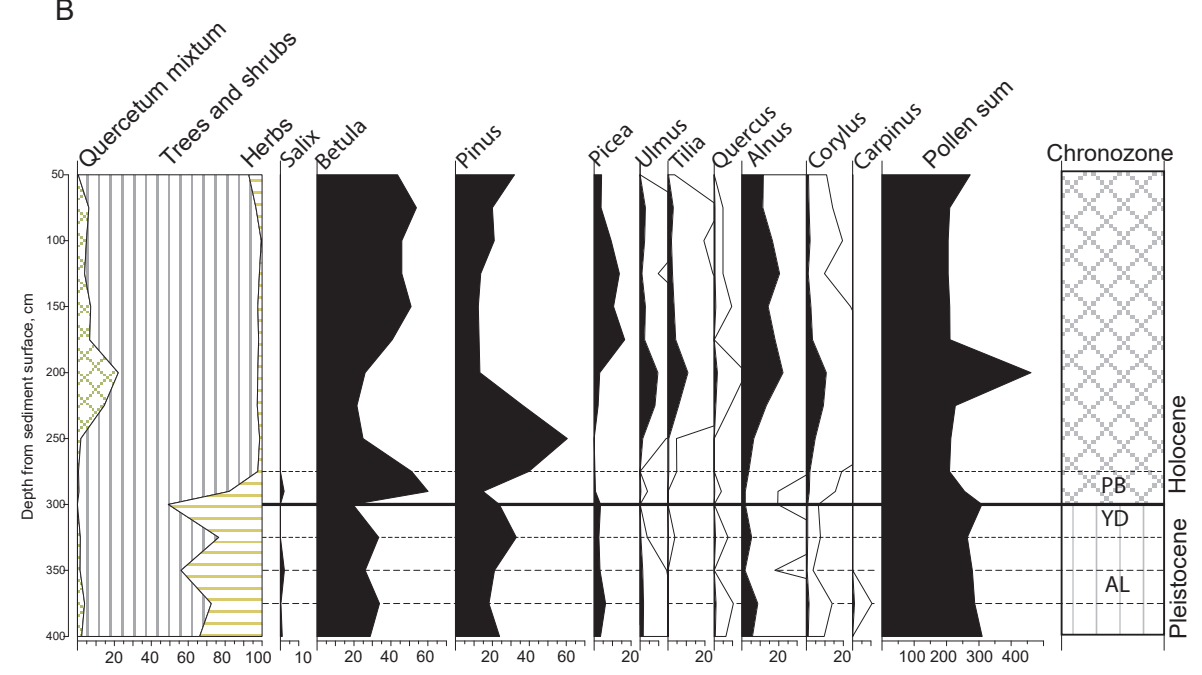




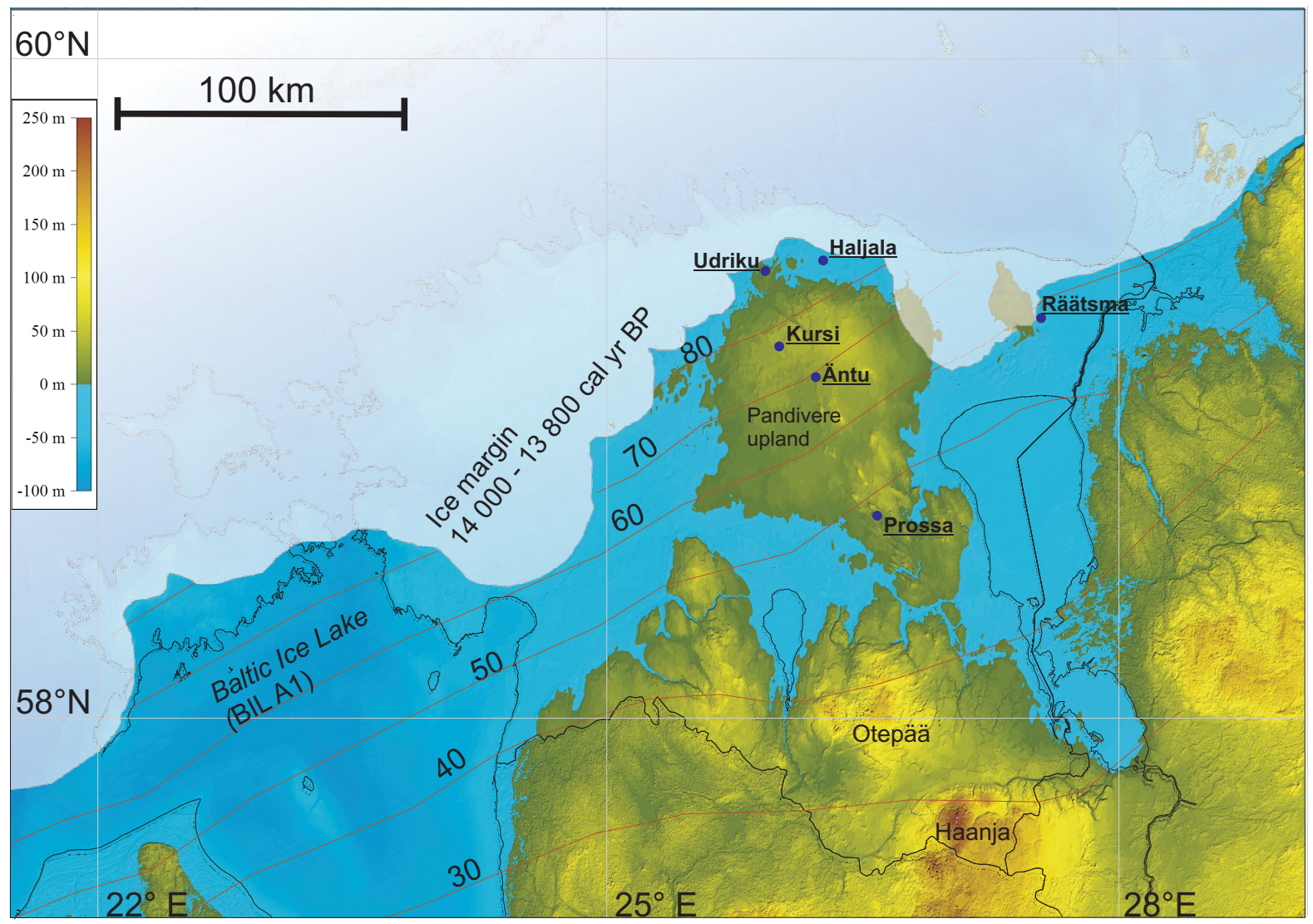

Fig. 5. Palaeogeography during the Pandivere stadial $14000-13800$ cal. yr BP. The ice marginal position and the BIL stage $A_{1}$ are based on Vassiljev \& Saarse (2013). Blue circles show the locations of the study sites discussed in the text.

consistent with that suggested for the Peipsi depression, which deglaciated simultaneously with the drumlin field area (Hang, 2001). The ice sheet decay at the Pandivere Upland proceeded under conditions of active and dead ice (Raukas, 2009) and was completed in the Allerød chronozone. In the depressions, the hollows and gullies of dead ice obviously remained longer based on the start of deposition in Äntu Sinijärv (Saarse \& Liiva, 1995; Laumets et al., 2014) and several mires (Veber, 1965). An ice front reached and stagnated at the Pandivere marginal belt no later than $13800 \mathrm{cal}$. yr $\mathrm{BP}$, forming the shoreline of BIL stage $\mathrm{A}_{1}$ (Fig. 5). It is demonstrated by the bio- and chronostratigraphy from the Udriku, Haljala and Räätsma lakes (Table 2) and pollen records from the Lusiku, Auvere and Loobu mires located in the adjacent areas (Pirrus,
1965; Veber, 1965). In all abovementioned sites, the Allerød clayey deposits contained herb pollen characteristic of the late-glacial period. After that period, the ice receded to the coastal lowland and reached the southern coast of the Gulf of Finland at approximately $13100 \mathrm{cal}$. yr BP (Lunkka et al., 2004; Johansson et al., 2011).

Based on the distance between the Prossa and Udriku sites (ca $90 \mathrm{~km}$ ) and the AMS ${ }^{14} \mathrm{C}$ ages (ca 14400 and $13900 \mathrm{cal} . \mathrm{yr} \mathrm{BP}$ ), the ice recession rate was $180 \mathrm{~m} \mathrm{a}^{-1}$, which is almost half of that calculated for the Pärnu area based on varve chronology (340 $\mathrm{m} \mathrm{yr}^{-1}$ ) (Hang \& Kohv, 2013). The same discrepancy is also observed in Sweden, where the varved clay chronology shows a considerably faster ice recession rate than other dating methods (Ringberg \& Erlström, 1999). Calculated for 
the Pandivere Upland, the ice recession rate is comparable with that suggested for the Onega area (ca $200 \mathrm{~m} \mathrm{yr}^{-1}$ ) (Saarnisto \& Saarinen, 2001).

However, the obtained AMS radiocarbon dates do not reflect the exact timing of the deglaciation, but rather the start of terrestrial vegetation colonisation. The AMS ages are determined from plant remains and therefore include gaps between the deglaciation itself and suitable conditions for vegetation to sprout. Late-glacial vegetation development is restricted by several factors, including the harsh climate and species migration. One such factor is the vegetation colonisation period. Previous studies have shown that the colonisation of pioneer vegetation took only a few decades after the land became ice-free (Jones \& Henry, 2003; Heikkilä et al., 2009; Amon et al., 2014), which is within the error limits of the AMS age determination. Another factor for terrestrial floral development is connected with palaeohydrology and landscape. In the Baltic area, the late-glacial palaeo-landscape was mosaic and flooded by different ice-dammed lakes (Amon et al., 2014). During the initial stage presently overgrown Lake Kursi was a local ice-dammed lake (Fig. 1B, Öpik, 1937) and the ice margin was located within ten kilometres north of Lake Kursi. Varved clay deposited into this water body. A distinct sand layer (316-315.5 cm, Fig. 3) overlying a set of 20 varves has an erosional lower contact and, therefore, probably represents the drainage of the local ice-dammed lake from $128 \mathrm{~m}$ a.s.l. to $112 \mathrm{~m}$ a.s.l. The age obtained at the top of this layer is $-13600-14000$ cal. yr BP (Table 2). The first terrestrial plant remains are sedges (Carex spp.) and polar willows (Salix polaris) (Fig. 4A) and found in the drainage layer. This suggests that the terrestrial area around Lake Kursi already had a vegetation cover by that time and that the shoreline was sufficiently close to the coring point for macrofossils to be found in the sediments.

Current bio- and chronostratigraphical data confirm that the Pandivere Upland deglaciated between 14200 and 13800 cal. yr BP. However, other dating methods, such as ${ }^{10} \mathrm{Be}$ (Rinterknecht et al., 2006), OSL (Raukas \& Stankowski, 2005) and varve chronology (Hang \& Kohv, 2013), suggest an age of 300-500 years younger compared to the AMS ${ }^{14} \mathrm{C}$ dates, which provide a minimum age of deglaciation. Cosmogenic nucleid ${ }^{10} \mathrm{Be}$ might show a younger age due to a post-exposure relocation of boulders (Lüthgens \& Böse, 2012) or delayed exposure to cosmic rays (Heyman et al., 2011), but why there is almost a half-thousand year difference compared to the varve chronology and the slower ice retreat rate is a problem that requires future study.

\subsection{Late-glacial flora beyond and on the Pandivere Upland}

The first recognised vegetation development stage around Lake Kursi was a willow dwarf shrubdominated tundra, at approximately 13880 13700 cal. yr BP (Fig. 4A). The next vegetation type was a mountain avens (Dryas octopetala)dominated tundra at -13700 cal. yr BP. The landscape was treeless throughout the late-glacial period, but vegetation was probably more diverse and productive. The third notable change was the migration of dwarf birch. The first tree macrofossils found in Kursi core belong to tree-birch but due to the sedimentary gap their age is clearly within the Holocene. This conclusion is also supported by the rise in birch pollen at the beginning of the Preboreal (Fig. 4B).

The similarities of the plant macrofossil data between the study locations suggest that the prevalent late-glacial vegetation type in northeastern Estonia was treeless tundra until the Holocene, however, the dominant shrub and herb species vary between the sites. In Haljala, the mountain avens (Dryas octopetala)-dominated tundra was prevalent with occasional finds of dwarf shrub willow (Salix polaris) in the basal part and one dwarf birch (Betula nana) leaf in the upper part of the late-glacial sediment. In Udriku, the basal part of late-glacial sediments reveals the Salix polaris tundra completely replaced by mountain avens dominated tundra at -13600 cal. yr BP, with no findings of dwarf birch macrofossils until the Holocene. The 
late-glacial sediments of Äntu confirm the local presence of Dryas and dwarf birch tundra. The palaeobotanical data of the present study site, Lake Kursi, suggest treeless tundra conditions until the Holocene. The late-glacial plant macrofossil data from Lake Prossa started with Salix polaris tundra and was followed by Dryas tundra that later turned to dwarf birch dominated tundra with a Dryas component.

In general, the north-eastern late-glacial vegetation show the following succession of vegetation development: the first stage was dwarf shrub willow-dominated tundra replaced by (or mixed with) mountain avens-dominated tundra. The next stage was dwarf birch-dominated tundra: the further south, the more occurences of $B$. nana macrofossils (abundant in Prossa and Äntu, some in Kursi, one find in Haljala and none in Udriku). The generalised late-glacial tundra dynamics correspond well with modern high- and mid-arctic vegetation zones - Rønning (1996) defines the Salix polaris zone as a high-arctic vegetation unit and the Dryas octopetala zone as a mid-arctic vegetation unit.

The treeless tundra vegetation with arctic shrubs (Salix polaris, Dryas) clearly suggest severe late-glacial palaeoclimatic conditions in northeastern Estonia. Recent pollen-based temperature reconstructions from Lake Udriku show summer temperatures of $10.2-12.6{ }^{\circ} \mathrm{C}$ (Veski et al., 2015), but the results are biased due to the long transport of pollen over the treeless landscape and therefore overestimate the temperature range. The first pioneer tree species in the Baltic area is tree-birch (Amon et al., 2014) and the local presence of treebirch requires summer temperatures of $\sim 10-12{ }^{\circ} \mathrm{C}$ (Paus, 1995) or $>13.2^{\circ} \mathrm{C}$ (Odland, 1996), so the temperature in Pandivere probably did not reach these values.

\section{Conclusions}

Lithological proxies, plant macrofossils and AMS ${ }^{14} \mathrm{C}$ dates were employed to investigate the ice recession history, the age of the Pandivere ice-marginal belt and the late-glacial vegetation development in the region.

- The dates from Lake Prossa, located between the Otepää and Pandivere ice-marginal zones, indicate that this area was ice-free by approximately $14400 \mathrm{cal}$. yr BP, and support the age proposed for the Otepää zone (14700$14500 \mathrm{cal}$. yr BP). Taking into account the distance between Prossa and the Pandivere Upland as well as the ice recession rate, the deglaciation of the Pandivere Upland started at approximately $14200 \mathrm{cal}$. yr BP. This is a minimum age because the AMS radiocarbon dates were determined from plant remains and there is a lag between ice decay and vegetation colonisation.

- The Pandivere stadial lasted ca. 400 years, from 14200 to $13800 \mathrm{cal}$. yr BP, as confirmed by AMS ${ }^{14} \mathrm{C}$ dates. In hollows and depressions, dead ice obviously melted later.

- The ice recession rate was ca. $180 \mathrm{~m} \mathrm{yr}^{-1}$ and stagnation at the ice-marginal zone could have lasted approximately 20 years, as concluded from the varve chronology of the Pärnu area (Hang \& Kohv, 2013).

- Deglaciation of the northern slope of the upland and formation of the Pandivere marginal formations are closely connected with the appearance of the proglacial lake $A_{1}$, a bay of the BIL (Saarse et al., 2007; Rosentau et al., 2009). New radiocarbon data supports reassessing the onset of the proglacial lake $A_{1}$ from $13300 \mathrm{cal}$. yr BP (Rosentau et al., 2009) to 13800-14000 cal. yr BP (Vassiljev and Saarse, 2013). More records are required to clarify how proglacial lake waters affected ice melting and retreat and why the other dating methods show a younger age for the Pandivere ice-marginal belt. 
- The late-glacial vegetation type around the Pandivere Upland was tundra with local variation of dominant cold-tolerant shrub species. The generalised scheme for the vegetation development in the studied area is as follows: willow dwarf shrub-dominated tundra - mountain avens-dominated tundra - dwarf birch-dominated tundra, which indicates that north-eastern Estonia remained treeless until the Holocene.

\section{References}

Amon, L. \& Saarse, L., 2010. Postglacial palaeoenvironmental changes in the area surrounding Lake Udriku in North Estonia. Geological Quarterly 54, 85-94.

Amon, L., Veski, S. \& Vassiljev, J., 2014. Tree taxa immigration to the eastern Baltic region, southeastern sector of the Scandinavian glaciation during the Late-glacial period (14,500-11,700 cal. B.P.). Vegetation History and Archaeobotany 23, 207-216.

https://doi.org/10.1007/s00334-014-0442-6

Bronk-Ramsey, C., 2009. Bayesian analysis of radiocarbon dates. Radiocarbon, 51, 337-360. https://doi.org/10.1017/s0033822200033865

Grimm, E., 2011. Tilia software v. 1.7.16. Illinois State Museum. Research and Collection Center, Springfield.

Hang, T., 1997. Clay varve chronology in the Eastern Baltic area. GFF 119, 295-300. https://doi.org/10.1080/11035899709546491

Hang, T., 2001. Proglacial sedimentary environment, varve chronology and Late Weichselian development of the Lake Peipsi, eastern Estonia. Ph.D. thesis, Stockholm University, $44 \mathrm{p}$.

Hang, T., 2003. A local clay-varve chronology and proglacial sedimentary environment in glacial Lake Peipsi, eastern Estonia. Boreas 32, 416-426. https://doi.org/10.1080/03009480310003658

Hang, T. \& Kohv, M., 2013. Glacial varves at Pärnu, southwestern Estonia: a local varve chronology proglacial sedimentary environment. GFF 135, 273-281. https://doi.org/10.1080/11035897.2013.775598

Hausen, H., 1913. Materialien zur Kenntnis der Pleistozänen Bildungen in den Russischen Ostseeländern. Fennia 34, 1-181.

Heikkilä, M., Fontana, S.L. \& Seppä, H., 2009. Rapid Lateglacial tree population dynamics and ecosystem changes in the eastern Baltic region. Journal of Quaternary Science 24, 802-815.

https://doi.org/10.1002/jqs.1254

\section{Acknowledgements}

Dr L. Kalnina, Dr P. Johansson, an anonymous referee and co-editor Prof. J.-P. Lunkka are acknowledged for their critical remarks and suggestions. This study was supported by institutional research funding from IUT1-8 and ESF Grant 9031.

Heyman, J., Stroeven, A.P. \& Harbor, J.M. \& Caffe, M.W., 2011. Too young or too old: evaluating cosmogenic exposure dating based on an analysis SIS of compiled boulder exposure ages. Earth and Planetary Science Letters 302, 71-80. https://doi.org/10.1016/j.epsl.2010.11.040

Ilves, E., 1980. Tartu Radiocarbon dates X. Radiocarbon 22, 1084-1089.

Johansson, P., Lunkka, J. P. \& Sarala P., 2011. The Glaciation of Finland. In: Ehlers, J., Gibbard, P.L. \& Hughes, P.D. (Eds.), Quaternary Glaciations - extent and Chronology. A closer look. Elsevier, Amsterdam 2011, 105-114.

Jones, G.A. \& Henry, G.H.R., 2003. Primary plant succession on recently deglaciated terrain in the Canadian High Arctic. Journal of Biogeography 30, 277-296. https://doi.org/10.1046/j.1365-2699.2003.00818.x

Kalm, V., 2006. Pleistocene chronostratigraphy in Estonia, southeastern sector of the Scandinavian glaciation. Quaternary Science Reviews 25, 960-975. https://doi.org/10.1016/j.quascirev.2005.08.005

Kalm, V., 2012. Ice-flow pattern and extent of the last Scandinavian Ice Sheet southeast of the Baltic Sea. Quaternary Science Reviews 44, 51-59. https://doi.org/10.1016/j.quascirev.2010.01.019

Kalm, V., Raukas, A., Rattas, M. \& Lasberg, K., 2011. Pleistocene Glaciations in Estonia. In: Ehlers, J., Gibbard, P.L. \& Hughes, P.D. (Eds.), Quaternary Glaciations - extent and Chronology. A closer look. Elsevier, Amsterdam 2011, 95-104.

Karukäpp, R., 1997. Gotiglatsiaalne morfogenees Skandinaavia mandriliustiku kagusektoris [Gotiglacial morphogenesis in the southeastern sector of the Scandinavian continental glacier]. Dissertationes Geologicae Universitatis Tartuensis, 6. Tartu Ülikooli Kirjastus, Tartu, 54 p. (in Estonian with English summary).

Kihno, K., Saarse, L. \& Amon, L., 2011. Late Glacial vegetation, sedimentation and ice recession chronology in the surroundings of Lake Prossa, central Estonia. 
Estonian Journal of Earth Sciences 60, 147-158. https://doi.org/10.3176/earth.2011.3.03

Lasberg, K. \& Kalm, V., 2013. Chronology of Late Weichselian glaciation in the western part of the East European Plain. Boreas 42, 995-1007. https://doi.org/10.1111/bor.12016

Last, W.M., 2001. Textural analysis of lake sediments. In: Last, W.M. \& Smol, J.P. (Eds.), Tracking Environmental Change Using Lake Sediments. Volume 2: Physical and Geochemical Methods. Kluwer Academic Publishers, Dordrecht, 41-81.

Laumets, L., Kalm, V., Poska, A., Kele, S., Lasberg, K. \& Amon, L., 2014. Palaeoclimate inferred from $\otimes{ }^{18} \mathrm{O}$ and palaeobotanical indicators in freshwater tufa of Lake Äntu Sinijärv, Estonia. Journal of Paleolimnology 51, 99-111. https://doi.org/10.1007/s10933-013-9758-y

Lowe, J.J., Rasmussen, S.O., Björck, S., Hoek, W.Z., Steffensen, J.P., Walker, M.J.C., Yu, Z.C. \& the INTIMATE group, 2008. Synchronisation of palaeoenvironmental events in the North Atlantic region during the Last Termination: a revised protocol recommended by the INTIMATE group. Quaternary Science Reviews 27, 6-17.

https://doi.org/10.1016/j.quascirev.2007.09.016

Lunkka, J.P., Johansson, P., Saarnisto, M. \& Sallasmaa, O., 2004. Glaciation of Finland. In: Ehlers, J. \& Gibbard, P.L (Eds.) Quaternary Glaciations-Extent and Chronology. Part I: Europe. Elsevier, Amsterdam, 93-100.

Lüthgens, C. \& Böse, M., 2012. From morphostratigraphy to geochronology - on the dating of ice marginal positions. Quaternary Science Reviews 44, 26-36. https://doi.org/10.1016/j.quascirev.2010.10.009

Odland, A., 1996. Differences in the vertical distribution pattern of Betula pubescens in Norway and its ecological significance. Paläoklimaforschung 20, 43-59.

Öpik, A., 1937. Porkuni-Tamsalu ümbruse geoloogiast [On the geology of Porkuni-Tamsalu area]. Eesti Loodus 1, 50-57. (in Estonian).

Paus, A., 1995. The Late Weichselian and early Holocene history of tree birch in south Norway and the Bolling Betula time-lag in northwest Europe. Review of Palaeobotany and Palynology 85, 243-262. https://doi.org/10.1016/0034-6667(94)00130-C

Pirrus, R., 1965. Hilisjääaegsete setete stratigraafia Ida Eestis [On the stratigraphy of the lateglacial sediments in East Estonia]. Report, Institute of Geology at Estonian Academy of Sciences. Tallinn. 62 p. (in Estonian).

Pirrus, R. \& Raukas, A., 1996. Late-glacial stratigraphy in Estonia. Proceedings of the Estonian Academy of Sciences, Geology 45, 34-45.

Rähni, E., 1961. Viimase mandrijää taganemisest Póhja-Eestist. [Über das zurückweichen des Letzten inlandeises aus Nordestland]. In: Orviku, K. (ed) Geoloogiline kogumik. Hans Heidemanni trükikoda, Tartu, p. 70-83. (in Estonian with German summary).
Rähni, E., 1963. Geokhronologiya lentochnykh glin SeveroVostochnoj Estonii [On the geochronology of north-east Estonian varved clay]. ENSV TA Geoloogia Instituudi Uurimused 12, 81-94. (in Russian).

Ramsay, W., 1929. Niveauverschiebungen, Eisgestaute Seen und Rezession des Inlandeises in Estland. Fennia 52, $1-48$.

Raukas, A., 1986. Deglaciation of the Gulf of Finland and adjoining areas. Bulletin of the Geological Society of Finland 58, 21-33.

Raukas, A., 2004. Application of OSL and ${ }^{10} \mathrm{Be}$ techniques to the establishment of deglaciation chronology in Estonia. Proceedings of the Estonian Academy of Sciences, Geology 53, 267-287.

Raukas, A., 2009. When and how did the continental ice retreat from Estonia? Quaternary International 207, 50-57. https://doi.org/10.1016/j.quaint.2008.11.010

Raukas, A. \& Karukäpp, R., 1993. Geomorphology in Estonia. In: Walker, H.J. \& Grahau, W.E. (Eds.) Evolution of Geomorphology. John Wiley \& Sons, Amsterdam, 135142.

Raukas, A., Rähni, E. \& Miidel, A., 1971. Kraevye lednikovye obrazovaniya Severnoj Estonii [Marginal glacial formations in North Estonia]. Valgus, Tallinn, 226 p. (in Russian with English summary).

Raukas, A. \& Stankowski, W., 2005. Influence of sedimentological composition on OSL dating of glaciofluvial deposits: examples from Estonia. Geological Quarterly 49, 463-470.

Rindberg, B. \& Erlström, M., 1999. Micromorphology and petrography of Late Weichselian glaciolacustrine varves in southeastern Sweden. Catena 35, 147-177. https://doi.org/10.1016/S0341-8162(98)00098-8

Rinterknecht, V.R., Clark, P.U., Raisbeck, G.M., Yiou, F., Bitinas, A., Brook, E.J., Marks, L., Zelčs,V., Lunkka, J.P., Pavlovskaya, I.E., Piotrowski, J.A. \& Raukas, A., 2006. The Last Deglaciation of the Southeastern Sector of the Scandinavian Ice Sheet. Science 311, 1449-1452. https://doi.org/10.1126/science.1120702

Róuk, A.-M., 1987. Physiography of the central part of Saadjärv drumlin field with special reference to Lake Raigastvere and its surroundings. In: Raukas, A. \& Saarse, L. (Eds.) Palaeohydrology of the temperate zone II. Lakes. Valgus, Tallinn, 81-100.

Rønning O., 1996. The flora of Svalbard. Polarhandbok 10. Norsk Polarinstitutt, $184 \mathrm{p}$.

Rosentau, A., 2006. Development of proglacial lakes in Estonia. Dissertationes Geologicae Universitatis Tartuensis 18. Tartu University Press, Tartu, 113 p.

Rosentau, A., Hang, T. \& Kalm, V., 2007. Water-level changes and palaeogeography of proglacial lakes in eastern Estonia: synthesis of data from the Saadjärv Drumlin Field area. Estonian Journal of Earth Sciences 56, 85-100.

Rosentau, A., Vassiljev, J., Hang, T., Saarse, L. \& Kalm, V., 2009. Development of the Baltic Ice Lake in the eastern 
Baltic. Quaternary International 206, 16-23. https://doi.org/10.1016/j.quaint.2008.10.005

Saarnisto, M. \& Saarinen, T., 2001. Deglaciation chronology of the Scandinavian Ice Sheet from the Lake Onega basin to the Salpausselkä End Moraines. Global and Planetary Change 31, 387-405. https://doi.org/10.1016/S0921-8181(01)00131-X

Saarse, L., 1994. Donnye otlozheniya malykh ozer Estonii [Bottom deposits of small Estonian lakes]. Estonian Academy of Sciences, Institute of Geology, Tallinn, 230 p. (in Russian with English summary).

Saarse, L. \& Kärson, J., 1982. Osobennosti osadkonakopleniya v ozerakh Elistvere, Prossa I Pikkjärv [Sedimentological peculiarities of the lakes Elistvere, Prossa and Pikkjärv]. Proceedings of the Academy of Sciences of the Estonian SSR, Geology 31, 62-67 (in Russian with English summary).

Saarse, L. \& Liiva, A., 1995. Geology of the Äntu group of lakes. Proceedings of the Estonian Academy of Sciences, Geology 44, 119-132.

Saarse, L., Vassiljev, J., Rosentau, A. \& Miidel, A., 2007. Reconstruction late glacial shore displacement in Estonia. Baltica 20, 35-45.

Saarse, L., Niinemets, E., Amon, L., Heinsalu, A., Veski, S. \& Sohar, K., 2009. Development of the late glacial Baltic basin and the succession of vegetation cover as revealed at Palaeolake Haljala, northern Estonia. Estonian Journal of Earth Sciences 58, 317-333. https://doi.org/10.3176/earth.2009.4.10

Saarse, L., Heinsalu, A. \& Veski, S., 2012. Deglaciation chronology of the Pandivere and Palivere ice-marginal zones in Estonia. Geological Quarterly 56, 353-362.

Sandgren, P., Hang, T. \& Snowball, I. F., 1997. A Late Weichselian geomagnetic record from Lake Tamula, SE Estonia. GFF 119, 279-284. https://doi.org/10.1080/11035899709546488
Sohar, K. \& Kalm, V., 2008. A 12.8-ka-long palaeoenvironmental record revealed by subfossil ostracod data from lacustrine freshwater tufa in Lake Sinijärv, northern Estonia. Journal of Paleolimnology 40, 809-821. https://dx.doi.org/10.1007/s10933-008-9200-z

Tammekann, A., 1938. Die Endmoränen in Estland. Comtes Rendus du Congrès International de Gèographie Amsterdam. Gèogaphie Physique. Union Geographique Internationale, Leiden, p. 251-255.

Thomson P.W., 1929. Die regionale Entwicklungs-geschichte der Wälder Estlands. Acta et Commentationes Universitatis Tartuensis 17, 1-88.

Vassiljev, J. \& Saarse, L., 2013. Timing of the Baltic Ice Lake in the eastern Baltic. Bulletin of the Geological Society of Finland 85, 9-18.

Veber, K., 1961. Soo- ja järvesetete stratigraafiast Pandivere kórgustikul [Zur stratigraphie der Limnischen und der moorsedimente af dem Pandivere-Höhengebiet]. ENSV Teaduste Akadeemia Geoloogia Instituudi Uurimused VII, 105-114. (in Estonian with German summary).

Veber, K., 1965. Kirde-Eesti soode geoloogiast [On the geology of northeastern Estonian mires]. Ph.D. thesis. Saku, 342 p. (in Estonian).

Veski, S., Seppä, H., Stančikaitė, M., Zernitskaya, V., Reitalu, T., Gryguc, G., Heinsalu, A., Stivrins, N., Amon, L., Vassiljev, J. \& Heiri, O., 2015. Quantitative summer and winter temperature reconstructions from pollen and chironomid data between 15 and $8 \mathrm{ka} \mathrm{BP}$ in the BalticBelarus area. Quaternary International 388, 4-11. https://doi.org/10.1016/j.quaint.2014.10.059

Zelčs, V. \& Nartišs, M., 2014. Outlines of the Quaternary geology of Latvia. In: Zelčs, V. \& Nartišs, M. (Eds.), Late Quaternary terrestrial processes, sediments and history: from glacial to postglacial environments. Excursion guide and abstracts of the INQUA Peribaltic Working Group Meeting. University of Latvia, Riga, 9-15. 